\title{
Evaluation of draw solutions and commercially available forward osmosis membrane modules for wastewater reclamation at pilot scale
}

Beatriz Corzo $^{\mathrm{a}, \mathrm{b}^{*}}$, Teresa de la Torre ${ }^{\mathrm{a}}$, Carmen Sans ${ }^{\mathrm{b}}$, Enrique Ferrero ${ }^{\mathrm{a}}$, Jorge J.

$$
\text { Malfeito }^{\mathrm{a}}
$$

${ }^{a}$ Research and Development Department, Acciona Agua, Avinguda de les Garrigues 22, 08820, El Prat de Llobregat, Barcelona, Spain

${ }^{b}$ Department of Chemical Engineering and Analytical Chemistry, University of Barcelona, Marti i Franquès 1, 08028, Barcelona, Spain

Tel.:+34 933351500 e-mail address: beatriz.corzo.garcia@acciona.com

\begin{abstract}
An intensive evaluation of draw solutions (DS) was performed by focusing on the wastewater reuse applications of hybrid forward osmosis (FO) processes. The substances studied were potassium formate, potassium phosphate, magnesium sulphate, sodium chloride, sodium polyacrylate and polyethylene glycol, and their osmotic pressure, conductivity, $\mathrm{pH}$, thermostability, sunlight exposure, toxicity, FO filtration performance and replenishment costs were determined. Additionally, commercially available FO membrane modules were evaluated at pilot scale. The results revealed that the most relevant DS properties for wastewater reuse under the studied conditions were the DS regeneration method, DS replacement price, $\mathrm{pH}$ adjustment and toxicity. These properties were shown to be more relevant than filtration flux when a maximum DS osmotic pressure value of 10 bar was used. This was the limit for efficient DS recovery. When the different FO membranes were compared, thin-film composite (TFC) flat-
\end{abstract}


sheet membranes showed the highest flux and the highest salt rejection, and the lowest permeability and salt rejection values were presented by cellulose triacetate (CTA) hollow fibre membranes. Based on the information obtained, a TFC-FO/nanofiltration (NF) demonstration plant will be constructed next to the wastewater treatment plant (WWTP) in San Pedro del Pinatar, in the region of Murcia (Spain). This represents the world's first FO demonstration plant for municipal wastewater reclamation and its results will allow this technology to be evaluated for wastewater reuse for agricultural purposes.

Keywords: Forward osmosis, hybrid FO system, draw solutions, commercial FO membranes, pilot plant, water reclamation.

\section{Introduction}

The total volume of treated wastewater reused in Europe by 2025 will be $3,222 \mathrm{Mm}^{3} / \mathrm{yr}$. Spain shows the greatest reuse potential at over $1,200 \mathrm{Mm}^{3} /$ year, which represents around a third of the potential water reuse in Europe and will be used primarily for agricultural purposes [1]. The region of Murcia in southeastern Spain faces high water stress and claims to reuse $95 \%$ of its wastewater indirectly or directly [2]. Only highsalinity water, which cannot be directly reused in agriculture, is discharged into the sea. In order to minimize water loss and reuse this high-salinity water, reverse osmosis (RO) is commonly used.

FO has been evaluated in recent years as an alternative to RO [3]. Nevertheless, further research into FO systems is required in order to determine their real applicability. The FO process uses a semi-permeable membrane to effectively separate water from the 
solutes it contains. This separation is driven by an osmotic pressure gradient, such that a solution of high concentration (relative to that of the feed solution) called a draw solution (DS) is used to induce a net flow of water through the membrane into the DS stream, thus effectively separating the feed water from its solutes. After that, an efficient separation system between the DS and the product water is required, and this is highly dependent on the final water use; this step is avoidable only if fertigation is applied [4]. This fact makes the installation of a hybrid FO system essential. The study also revealed that, although hybrid technologies like FO combined with membrane bioreactors (FOMBR) or FO-RO have been proposed as promising technologies, there is still a lack of overall energy balance for these integrated and alternative systems that would allow them to be compared with conventional technology. In this regard, other recent reviews [5-7] have compared energy usage by FO-RO and RO alone (including adequate pretreatment) and concluded that reverse osmosis is more energy efficient due to the DS recovery step, which implies a high energy input. Moreover, with the commercial technology currently available, FO systems for wastewater treatment seem to involve higher capital costs than conventional technologies [8]. However, a hybrid process like FO-RO may be advantageous if all costs incurred are considered, rather than only energy and capital costs. The reason for this is basically the lower fouling propensity reported for the FO process [9-11] compared to conventional membrane technologies applied to wastewater treatment, which would theoretically reduce the need for chemicals throughout the whole process. This is due to a lack of $\mathrm{pH}$ adjustment and antiscalant in the pretreatment and reduced chemical cleaning frequency [12-14]. This is important not only because of the reduction in chemicals used, but also because of the corresponding reduction in plant shutdowns. This advantage means that the FO process is not intended to replace RO, but is rather proposed as a way to process feed waters 
that cannot be treated by RO [12]. Moreover, FO systems present a greater rejection of contaminants than UF and MF membranes $[15,16]$. Therefore, another important benefit of hybrid FO processes is their high rejection due to the dual barrier (FO and NF or RO), which may solve rejection problems if the system is adequately customized for the targeted compounds.

Different authors have reviewed the application of forward osmosis for wastewater reclamation $[12,17-19]$. The FO membrane flux and the selection of the DS were identified as the main problems to be solved in this application [20]. It is necessary to identify a low cost DS that can generate high osmotic pressures, and is non-toxic and economically separable [3]. The ideal DS allows high flux with low salt diffusion to the feed side and is easy to separate in order to recover the water from the diluted DS. In addition to these requirements, the DS has to meet maximum diffusion through the porous membrane support in order to avoid osmotic pressure and flux decline $[21,22]$. The lack of diffusion through the porous support is known as internal concentration polarization (ICP) and causes either dilution of the DS or concentration of the feed solution, depending on whether the DS or the feed is being run along the active membrane layer [23, 24]. For the specific application of wastewater reuse, DS concentration in the final product water must be below the standards reflected in the corresponding wastewater reuse regulations.

A demonstration plant will be constructed in order to evaluate the hybrid FO technology applied to high-salinity wastewater treatment plant (WWTP) effluent for irrigation purposes. This paper describes the preliminary studies that were carried out prior to the final design of the plant. Accordingly, a systematic assessment of the effect of DS on FO performance was carried out using experimental filtration data. The chemical properties of the DS, their cost and the potential for economic recovery were evaluated. 
Finally, several commercial FO membranes were evaluated in terms of water permeability and salt rejection.

\section{Materials and methods}

\subsection{Feed water}

Synthetic feed water was prepared with deionized water adjusted with $\mathrm{NaCl}$ to $5 \mathrm{mS} / \mathrm{cm}$ of conductivity (concentration and osmotic pressure of $2.72 \mathrm{~g} \mathrm{~L}^{-1}$ and 2 bar, respectively), to make it similar to the feed water coming from the WWTP effluent at San Pedro del Pinatar.

\subsection{FO membranes}

Five commercial FO modules were used for the performance tests: two FO 4040 spiral wound (SW) membranes with an area of $3 \mathrm{~m}^{2}$ made of cellulose triacetate (CTA) and thin-film composite (TFC), respectively, one FO 4040 spiral wound membrane with an area of $4.12 \mathrm{~m}^{2}$ made of TFC, one FO flat-sheet (FS) membrane with an area of $1.3 \mathrm{~m}^{2}$ made of TFC, and one FO hollow fibre (HF) with an area of $25 \mathrm{~m}^{2}$ made of CTA. In all membranes, the active layer faced the feed solution.

\subsection{Chemicals}

The different DSs (potassium formate, potassium phosphate, magnesium sulphate and sodium chloride, all with $>98 \%$ purity) were purchased from Barcelonesa de Drogas y Productos Químicos (Spain). Sodium polyacrylate 6500 Da (previously diluted: $43 \%$ w/w) and polyethylene glycol 10,000 Da were bought from Kemira Ibérica (Spain) and Sigma Aldrich, respectively. The $\mathrm{pH}$ was adjusted with $\mathrm{HCl} 1 \mathrm{M}$ or $\mathrm{NaOH} 1 \mathrm{M}$ solutions from Panreac.

\subsection{DS performance tests: water flux (Jw) and reverse salt diffusion (Js)}


The FO filtration tests were performed with the $4.12 \mathrm{~m}^{2}$ spiral wound (SW) membrane. Two kinds of experiment were carried out. First, the initial DS concentration in every FO run was set to 40 bar of osmotic pressure and the synthetic feed water was prepared as described in Section 2.1. The synthetic feed water (FW) concentration $\left(2.72 \mathrm{~g} \mathrm{~L}^{-1}\right.$ of $\mathrm{NaCl})$ and temperature $\left(25^{\circ} \mathrm{C}\right)$ were kept constant throughout the whole test. The water passing through the membrane progressively diluted the DS, thereby covering a wide range of osmotic pressure values. This made it possible to obtain a wide range of operational point data in a single experiment, in which different normalized water fluxes (Jw) were tested.

In addition, for every DS selected, the osmotic pressure of both the synthetic feed water and the DS were kept constant at 2 bar and 10 bar, respectively, for 2 hours at $25^{\circ} \mathrm{C}$. The DS concentration in the synthetic feed water tank was therefore monitored to check the normalized reverse salt diffusion (Js) from the DS side to the feed water side.

A process diagram of the pilot plant used is presented in Figure 1. The operating conditions of the membrane used were those recommended by the manufacturer and were kept constant throughout the whole test (Table 1). The recommended cross-flow velocity $(100-200 \mathrm{~cm} / \mathrm{s})$ was also maintained. When each DS test ended, a flushing operation was carried out using DI water and a FO membrane test (see the description in Section 2.5) was performed to check the initial membrane properties.

\subsection{FO membrane performance tests}

FO tests were performed for all commercial membranes in a pilot test plant (Figure 1) under the same initial DS conditions (75 $\mathrm{g} \mathrm{L}^{-1}$ of $\mathrm{NaCl}$ in deionized water). The synthetic feed water $(\mathrm{FW})$ concentration $\left(2.72 \mathrm{~g} \mathrm{~L}^{-1}\right.$ of $\left.\mathrm{NaCl}\right)$ and temperature $\left(25^{\circ} \mathrm{C}\right)$ were kept constant throughout the whole test. No pH adjustment was carried out. Total 
dissolved solids (TDS) were measured constantly in both solutions in order to determine the salt rejection of each membrane. The operating conditions, which followed each manufacturer's recommendations and were adapted to the test pilot plant, are listed in Table 1.

\subsection{Analytical methods}

The osmotic pressure was measured using an Osmomat ${ }^{\circledR} 030$ Cryoscopic Osmometer from Gonotec. TDS and conductivity measurements were performed with a Crison CM 35 conductivity meter with temperature compensation. Ecotoxicity measurements were carried out with an Optocomp I luminometer from MGM instruments, in accordance with standard ISO 11348-3:2007, using bioluminescent Vibrio fischeri bacteria. In order to carry out these measurements, the osmotic pressure of the sample had to be controlled at around 20 bar (osmotic pressure of $25 \mathrm{~g} / \mathrm{L} \mathrm{NaCl}$ solution) so as to ensure a proper osmotic balance of bacteria and confirm that the reduction in light emission was due solely to the effect of the discharges. Stability studies of the DSs, in terms of temperature and sunlight exposure, were performed using a solution with 15 bar of osmotic pressure.

\section{Results and discussion}

\subsection{DS selection}

The most interesting DSs were selected based on their fundamental properties. The properties that most influence water flux $(\mathrm{Jw})$ in FO are the van ' $t$ Hoff coefficient, which makes high osmotic pressure possible, and diffusivity, which lowers ICP [21, 25, 26]; a clear understanding of the relative contribution of these properties to the final performance is therefore highly relevant when selecting a DS. Moreover, selection of 
the DS depends on the final use of the product water. For instance, if the final use is irrigation, a fertilizer can be used for direct fertigation $[4,27]$.

All these factors were considered in order to identify solutes that fulfil the optimal properties calculated and are economically viable. The following groups of substances were selected from the most interesting potential DSs identified: potassium formate (HCOOK), which is a short-chain organic salt with a high diffusivity that prevents ICP of the FO membrane; potassium phosphate $\left(\mathrm{K}_{4} \mathrm{P}_{2} \mathrm{O}_{7}\right)$, which has the advantage of possessing fertilizer properties and providing high osmotic pressure; high molecular weight (MW) polymers that, despite presenting low diffusivity and therefore high ICP potential, can be separated using ultrafiltration (UF) [28, 29], two types were evaluated: polyacid salts and polyalcohols; magnesium sulphate $\left(\mathrm{MgSO}_{4}\right)$, which can be separated using NF and requires less energy than RO for separation. And finally, sodium chloride $(\mathrm{NaCl})$ was selected as a reference DS for several reasons: it is generally used for standard membrane tests; seawater and RO concentrate are widely used as DSs in several interesting applications and it allows the results obtained to be compared with data from the literature, in which $\mathrm{NaCl}$ is commonly used as a DS.

To assess the performance of the different DSs that were selected in the FO process, a number of studies were carried out, including: physicochemical characterization, including toxicity and stability studies, hydraulic tests with the results of determining $\mathrm{JW}$ and Js generated at different osmotic pressures, and an estimation of the costs associated with using the different DSs in an hypothetical FO+RO process.

\subsubsection{Physicochemical characterization}

Figure 2 shows the results of osmotic pressure versus DS concentration. Figure 2 shows a linear relationship between DS concentration and osmotic pressure only at low 
concentrations, and at some point a deviation with exponential growth, which can be attributed to the variation in freezing-point depression, a colligative property of the solution. The $\mathrm{NaCl}$ solution was the DS that produced the highest osmotic pressure, followed by the $\mathrm{HCOOK}, \mathrm{MgSO}_{4}$ and $\mathrm{K}_{4} \mathrm{P}_{2} \mathrm{O}_{7}$ solutions.

As shown in Figure 3, the conductivity increased proportionally to the concentration and, consequently, to the osmotic pressure at low DS concentrations, except for polyethylene glycol. Thus, if this product is excluded, it is possible to conclude that conductivity measurements represent a useful parameter for process control in the pilot plant due to the dependence between conductivity and concentration in these products.

Ecotoxicity tests were applied to the different DSs, except for $\mathrm{NaCl}$, as shown in Table 2. The results of these assays were expressed as $E C_{50}$, which represents the percentage of sample dilution (w/w) that causes a $50 \%$ reduction in bacteria luminescence after a contact time of 15 minutes. Only polyethylene glycol was found to be toxic, and this product was therefore discarded.

Regarding the sunlight and thermostability of each DS, it was observed that the osmotic pressure and conductivity of DS samples remained unchanged for two months; only the sodium polyacrylate samples showed different coloration and suspended solids.

\subsubsection{DS performance tests: Jw and Js measurements}

Figure 4 shows the $\mathrm{Jw}$ measurements obtained with the selected DSs for the osmotic pressure range studied. As Figure 4 shows, potassium formate was the DS that performed the best in terms of water flux. There were no significant differences in water flux between phosphate, sodium chloride and high MW polymer. $\mathrm{MgSO}_{4}$ showed the lowest flux out of the DSs tested. These results can be attributed to the higher diffusion coefficient of monovalent electrolytes as compared to bivalent electrolytes [30, 31]. 
This is known to increase ICP in divalent electrolytes when the feed faces the active side of the membrane, and therefore results in a lower water flux. Some asymptotic behaviour was observed with each DS. Increasing DS concentrations have been reported to result in higher water fluxes, but this relationship does not follow a linear correlation $[30,31]$. This was shown to be caused by the higher ICP levels induced by the increase in water fluxes [32-34]. These empirical results make it possible to conclude that there is a point above which Jw does not increase significantly when the DS osmotic pressure or DS concentration is increased, and operating at a concentration higher than this level would therefore offer no advantages in the FO process. In fact, a higher concentration would be detrimental to the recovery process, so this point will be the concentration limit for operations. Therefore, it will be necessary to reach a compromise between Jw and osmotic pressure when the appropriate DS concentration in the FO process is selected. The lower the DS concentration, the lower the energy used in the recovery process, so a maximum DS osmotic pressure of 10 bar was considered for the design of the demonstration plant in order to make the recovery process more energetically competitive. At $10 \mathrm{bar}$, the membrane performance in terms of $\mathrm{Jw}$ was very similar for all DSs tested, except for formate (Figure 4), which presented a higher performance than the other DSs. As shown in Figure 2, the osmotic pressure of each DS differs depending on its concentration. The quantity of product required to prepare the different DSs to reach an osmotic pressure of 10 bar is lower in monovalent salts than in divalent salts. It is important to note that the sodium polyacrylate supplied was previously diluted with water. However, high MW substances require a higher amount of product due to their low molality and low Van 't Hoff factor, according to the Morse equation given below (Equation 1):

\section{$\Pi=\operatorname{im} \rho R T \quad$ Equation 1}


Where $\Pi$ is osmotic pressure [atm], $i$ is the Van ' $t$ Hoff factor, $m$ is molality [mol $\mathrm{Kg}^{-1}$ ], $\rho$ is density $\left[\mathrm{Kg} \mathrm{L}^{-1}\right], \mathrm{R}$ is the molar gas constant $\left(0.082\right.$ atm $\left.\mathrm{L} \mathrm{K}^{-1} \mathrm{~mol}^{-1}\right)$ and $\mathrm{T}$ is temperature $[\mathrm{K}]$.

For a given type of DS, the Js increased as the DS concentration increased [35]. Js adversely affects the FO and subsequent processes, not only by reducing the driving force and contaminating the feed solution, but also by increasing the replenishment cost of the draw solute. Therefore, minimizing Js is vital for obtaining a competitive FO process [36].

Table 3 shows the normalized $\mathrm{Jw}$, Js and $\mathrm{J}_{\mathrm{S}} / \mathrm{JW}_{\mathrm{W}}$ (specific reverse solute flux, SRSF) measured in the synthetic feed water tank for every DS during an FO test in which the DS osmotic pressure was maintained at 10 bar.

Sodium polyacrylate showed the minimum SRSF in accordance with its high MW and low diffusivity. DSs made of monovalent electrolytes showed the highest SRSF, a finding consistent with the results reported by Cornelissen et al. [30].

\subsubsection{Cost estimation}

One of the most important factors in the operational expenditure (OPEX) of this hybrid FO system is the replacement of the DS caused by salt leakage from the DS side to the feed side of the membrane and its incomplete recovery during the second stage. In addition, several DSs have a strong basic or acid $\mathrm{pH}$ value. Consequently, in order to ensure that the membrane is properly maintained and performs well, and to obtain a near-neutral effluent, the $\mathrm{pH}$ must be adjusted, thereby increasing operating costs. All of the abovementioned costs are shown in Table 4. Polyethylene glycol was discarded due to its toxicity (Table 2) and its replacement cost was therefore not calculated. 
The DS selection process is strongly determined by OPEX. When replenishment cost alone is considered, sodium chloride is the cheapest option, followed by magnesium sulphate. Formate, sodium polyacrylate and phosphate could be excluded from the final DS selection because of their expensive replacement costs. However, sodium polyacrylate, phosphate and magnesium sulphate can be separated by UF and/or NF, respectively, and thus have lower energy requirements than RO. DS recovery is one of the key factors for implementing a hybrid FO system successfully [29]. According to Mulder [37], hydraulic filtration resistance increases from UF to RO membranes $(\mathrm{RO}>\mathrm{NF}>\mathrm{UF})$, with UF membranes offering the lowest energy demand for the same Jw. However, UF membranes do not have the capacity to structurally support high feed hydraulic pressures, so according to Darcy's law (Equation 2), the Jw would be too low for DSs with a high MW (high $\Delta \Pi$ ) or the salt rejection would be very poor for DSs with a low MW (low $\Delta \Pi$ ). This fact makes it possible to conclude that NF membranes represent the most promising technology for the second stage in a hybrid FO system, in line with the findings of Luo et al. [29].

$$
J w=\frac{\Delta P-\Delta \Pi}{R \cdot \mu} \quad \text { Equation } 2[37]
$$

Where $\mathrm{Jw}$ is the flux through the membrane, $\mathrm{R}$ is the hydraulic resistance, $\Delta \mathrm{P}$ is the hydraulic pressure differential between the feed and permeate sides, $\Delta \Pi$ is the osmotic pressure differential between the feed and permeate sides, and $\mu$ is the fluid dynamic viscosity.

On the other hand, boron removal improves at higher $\mathrm{pH}$ values. If this is taken into account, formate and phosphate could represent an interesting choice of DS, despite the costs associated with the $\mathrm{pH}$ adjustment required due to their high $\mathrm{pH}$ values.

\subsubsection{Analysis of the overall results}


A decision matrix was created based on these results and is presented in Table 5.

The results showed that DS replacement cost, $\mathrm{pH}$ adjustment and toxicity were the most relevant properties for a DS. These are more important than filtration flux, since the flux differences presented by the different DSs in a real commercial membrane at low concentrations were not as significant due to the occurrence of ICP.

Another important factor is the DS regeneration method used, since some of the salts studied can be separated by NF, a method that consumes less energy consumption than separation by RO. The most suitable DS candidate should therefore be low cost, with a high van 't Hoff factor to save on replenishment costs, have a neutral or alkali $\mathrm{pH}$ value, be non-toxic and offer a recovery method with low energy requirements. When all of these factors and the tests results are taken into account, the most promising DS candidates for the demonstration plant were $\mathrm{MgSO}_{4}$, sodium polyacrylate and $\mathrm{K}_{4} \mathrm{P}_{2} \mathrm{O}_{7}$.

\subsection{FO membrane performance tests}

To assess the performance of the commercial FO membranes selected, the water fluxes generated by the $\mathrm{NaCl} \mathrm{DS}$ at different osmotic pressures were tested. Figure 5 shows the water flux measurements obtained for the range of DS osmotic pressures studied.

All of the membranes tested were oriented so that the active side faced the feed. Although a higher water flux is achieved when the DS is on the active layer side, since ICP is less severe, operating with the active side facing the feed is recommended when the feed water has a high fouling potential $[32,38]$. At the demonstration plant, real WWTP effluent will be used as feed water, and running the DS along the active side is therefore expected to increase ICP values due to the reduction in support membrane porosity $[32,33]$. 
As our results show, the flat-sheet membrane module exhibited the best performance in terms of flux, especially at high DS osmotic pressures. The lowest water permeability was obtained with the CTA membrane modules, whose material presented not only lower water permeability but also lower salt rejection. These results are consistent with the findings reported by Shaffer et al. [6]. CTA hollow fibre configuration is not the most suitable membrane for this application due to the lower water flux and salt rejection values. When 10 bar of osmotic pressure is taken as a reference, the TFC flatsheet module achieved $9 \mathrm{~L} \mathrm{~m}^{-2} \mathrm{~h}^{-1}$ of permeate flux, while the CTA membranes achieved fluxes below $3 \mathrm{~L} \mathrm{~m}^{-2} \mathrm{~h}^{-1}$. The rest of spiral wound TFC membranes resulted in values of $5 \mathrm{~L} \mathrm{~m}^{-2} \mathrm{~h}^{-1}$. Although all membrane providers guarantee salt rejection of around $99 \%$, this rejection was highly dependent on FW and DS concentration. Under the test conditions studied (see Section 2.5), salt rejection values were around 97\%98\%, with slightly higher values in TFC spiral wound and flat-sheet membranes and slightly lower values in the CTA hollow fibre membranes.

With regard to cost, capital expenditure (CAPEX) was not considered, since commercial FO membrane market prices are expected to fall in the short to medium term due to a rise in demand. Currently, all of these membranes are relatively expensive, since most manufacturers are small companies or startups. As a result, this paper focused solely on OPEX.

TFC-FO membranes were then selected for the demonstration plant according to the best permeability and rejection properties reported in our results.

\section{Conclusions}

The application of a hybrid FO system for wastewater reclamation was studied, with a particular focus on selecting the most appropriate commercial DS and FO membrane. 
Accordingly, a number of DS to be used in a hybrid FO process were studied, and several properties were taken into account. These included osmotic pressure, conductivity, $\mathrm{pH}$, thermostability, sunlight exposure, toxicity, Jw, Js, the regeneration method and the DS replacement costs. Replacement costs, $\mathrm{pH}$ and toxicity were the most relevant properties in an optimal DS. Thus, an analysis of all the test results made it possible to select $\mathrm{MgSO}_{4}$, sodium polyacrylate and $\mathrm{K}_{4} \mathrm{P}_{2} \mathrm{O}_{7}$ as DS candidates for the hybrid FO demonstration plant. A maximum osmotic pressure of 10 bar was selected as the optimal operating pressure for the DS in the hybrid FO system. Moreover, several commercial FO membranes were evaluated in terms of water permeability and salt rejection. TFC flat-sheet membranes showed the highest flux and the highest salt rejection. CTA hollow fibre membranes presented the lowest permeability and salt rejection. TFC flat-sheet membranes were therefore selected for the demonstration plant since they offered the most advantageous hydraulic properties. To conclude, a hybrid FO demonstration plant will be constructed using TFC-FO/NF membranes.

\section{Acknowledgements}

The research leading to these results was funded by the European Commission's LIFE+ Programme (LIFE12/ENV/ES/000632 LIFE OFREA). Beatriz Corzo extends a special thank you to the Catalan government for the Industrial PhD Programme grant (DI2014).

\section{$5 \quad$ References}

[1] "Optimising water reuse in the EU," Stakeholder workshop on water reuse, 2014. [Online]. Available: http://ec.europa.eu/environment/water/blueprint/pdf/ BIO_Water Reuse Public Consultation Report_Final.pdf. [Accessed: 12-Feb2015]. 
[2] "Entidad Regional de Saneamiento y Depuración de Aguas Residuales (ESAMUR)," 2012. [Online]. Available: www.esamur.com. [Accessed: 31-Dec2012].

[3] T.-S. Chung, S. Zhang, K. Y. Wang, J. Su, and M. M. Ling, "Forward osmosis processes: Yesterday, today and tomorrow," Desalination, vol. 287, pp. 78-81, 2012.

[4] S. Phuntsho, H. K. Shon, S. Hong, S. Lee, and S. Vigneswaran, "A novel low energy fertilizer driven forward osmosis desalination for direct fertigation: Evaluating the performance of fertilizer draw solutions," J. Membr. Sci., vol. 375, no. 1-2, pp. 172-181, 2011.

[5] R. K. McGovern and J. H. Lienhard, "On the potential of forward osmosis to energetically outperform reverse osmosis desalination," J. Membr. Sci., vol. 469. pp. 245-250, 2014.

[6] D. L. Shaffer, J. R. Werber, H. Jaramillo, S. Lin, and M. Elimelech, "Forward osmosis: Where are we now?,” Desalination, vol. 356. pp. 271-284, 2015.

[7] N. M. Mazlan, D. Peshev, and A. G. Livingston, "Energy consumption for desalination - A comparison of forward osmosis with reverse osmosis, and the potential for perfect membranes," Desalination, vol. 377, pp. 138-151, 2016.

[8] V. Yangali-Quintanilla, Z. Li, R. Valladares, Q. Li, and G. Amy, "Indirect desalination of Red Sea water with forward osmosis and low pressure reverse osmosis for water reuse," Desalination, vol. 280, no. 1-3, pp. 160-166, 2011.

[9] B. Mi and M. Elimelech, "Organic fouling of forward osmosis membranes: Fouling reversibility and cleaning without chemical reagents," J. Membr. Sci., 
vol. 348, no. 1-2, pp. 337-345, 2010.

[10] S. Lee, C. Boo, M. Elimelech, and S. Hong, "Comparison of fouling behavior in forward osmosis (FO) and reverse osmosis (RO)," J. Membr. Sci., vol. 365, no. 1-2, pp. 34-39, 2010.

[11] M. Xie, J. Lee, L. D. Nghiem, and M. Elimelech, "Role of pressure in organic fouling in forward osmosis and reverse osmosis," J. Membr. Sci., vol. 493, pp. 748-754, 2015.

[12] R. Valladares Linares, Z. Li, S. Sarp, S. S. Bucs, G. Amy, and J. S. Vrouwenvelder, "Forward osmosis niches in seawater desalination and wastewater reuse," Water Res., vol. 66. pp. 122-139, 2014.

[13] W. S. Ang, S. Y. Lee, and M. Elimelech, "Chemical and physical aspects of cleaning of organic-fouled reverse osmosis membranes," J. Membr. Sci., vol. 272, no. 1-2, pp. 198-210, 2006.

[14] W. S. Ang, A. Tiraferri, K. L. Chen, and M. Elimelech, "Fouling and cleaning of RO membranes fouled by mixtures of organic foulants simulating wastewater effluent,” J. Membr. Sci., vol. 376, no. 1-2, pp. 196-206, 2011.

[15] A. Achilli, T. Y. Cath, E. A. Marchand, and A. E. Childress, "The forward osmosis membrane bioreactor: A low fouling alternative to MBR processes," Desalination, vol. 238, no. 1-3, pp. 10-21, 2009.

[16] R. W. Holloway, A. E. Childress, K. E. Dennett, and T. Y. Cath, "Forward osmosis for concentration of anaerobic digester centrate," Water Res., vol. 41, no. 17, pp. 4005-4014, 2007. 
[17] K. Lutchmiah, A. R. D. Verliefde, K. Roest, L. C. Rietveld, and E. R. Cornelissen, "Forward osmosis for application in wastewater treatment: A review," Water Res., vol. 58. pp. 179-197, 2014.

[18] S. Zhao, L. Zou, C. Y. Tang, and D. Mulcahy, "Recent developments in forward osmosis: Opportunities and challenges," J. Membr. Sci., vol. 396. pp. 1-21, 2012.

[19] D. Roy, M. Rahni, P. Pierre, and V. Yargeau, "Forward osmosis for the concentration and reuse of process saline wastewater," Chem. Eng. J., vol. 287, pp. 277-284, 2016.

[20] N. Akther, A. Sodiq, A. Giwa, S. Daer, H. A. Arafat, and S. W. Hasan, "Recent advancements in forward osmosis desalination: A review," Chem. Eng. J., vol. 281, pp. 502-522, 2015.

[21] T. Y. Cath, A. E. Childress, and M. Elimelech, "Forward osmosis: Principles, applications, and recent developments," J. Membr. Sci., vol. 281, no. 1-2. pp. $70-87,2006$.

[22] J. Su, S. Zhang, M. M. Ling, and T.-S. Chung, "Forward osmosis: an emerging technology for sustainable supply of clean water," Clean Technol. Environ. Policy, vol. 14, no. 4, pp. 507-511, 2012.

[23] J. R. McCutcheon and M. Elimelech, "Influence of concentrative and dilutive internal concentration polarization on flux behavior in forward osmosis," $J$. Membr. Sci., vol. 284, no. 1-2, pp. 237-247, 2006.

[24] G. T. Gray, J. R. McCutcheon, and M. Elimelech, "Internal concentration polarization in forward osmosis: role of membrane orientation," Desalination, vol. 197, no. 1-3, pp. 1-8, 2006. 
[25] A. K. H. D’Haese, M. M. Motsa, P. Van der Meeren, and A. R. D. Verliefde, “A refined draw solute flux model in forward osmosis: Theoretical considerations and experimental validation," J. Membr. Sci., vol. 522, pp. 316-331, 2017.

[26] W. C. L. Lay, J. Zhang, C. Tang, R. Wang, Y. Liu, and A. G. Fane, "Factors affecting flux performance of forward osmosis systems," J. Membr. Sci., vol. 394-395, pp. 151-168, 2012.

[27] Y. Kim et al., "Selection of suitable fertilizer draw solute for a novel fertilizerdrawn forward osmosis-anaerobic membrane bioreactor hybrid system," Bioresour. Technol., vol. 210, pp. 26-34, 2016.

[28] Q. Ge, J. Su, G. L. Amy, and T. S. Chung, "Exploration of polyelectrolytes as draw solutes in forward osmosis processes," Water Res., vol. 46, no. 4, pp. 13181326, 2012.

[29] H. Luo et al., "A review on the recovery methods of draw solutes in forward osmosis," J. Water Process Eng., vol. 4, no. C. pp. 212-223, 2014.

[30] E. R. Cornelissen et al., "Membrane fouling and process performance of forward osmosis membranes on activated sludge," J. Membr. Sci., vol. 319, no. 1-2, pp. 158-168, 2008.

[31] J.-J. Qin et al., "Optimization of Operating Conditions in Forward Osmosis for Osmotic Membrane Bioreactor," Open Chem. Eng. J., vol. 3, no. 1, pp. 27-32, 2009.

[32] C. Y. Tang, Q. She, W. C. L. Lay, R. Wang, and A. G. Fane, "Coupled effects of internal concentration polarization and fouling on flux behavior of forward osmosis membranes during humic acid filtration," J. Membr. Sci., vol. 354, no. 
1-2, pp. 123-133, 2010.

[33] H. Zhang, Y. Ma, T. Jiang, G. Zhang, and F. Yang, "Influence of activated sludge properties on flux behavior in osmosis membrane bioreactor (OMBR)," $J$. Membr. Sci., vol. 390-391, pp. 270-276, 2012.

[34] S. Phuntsho, S. Sahebi, T. Majeed, F. Lotfi, J. E. Kim, and H. K. Shon, "Assessing the major factors affecting the performances of forward osmosis and its implications on the desalination process," Chem. Eng. J., vol. 231, pp. 484496, 2013.

[35] H. K. Wang, J.; Pathak, N.; Chekli, L.; Phuntsho, S.; Kim, Y.; Li, D.; Shon, "Performance of a Novel Fertilizer-Drawn Forward Osmosis Aerobic Membrane Bioreactor (FDFO-MBR): Mitigating Salinity Build-Up by Integrating Microfiltration," Water, vol. 9, no. 1, p. 21, 2017.

[36] Q. Ge, M. Ling, and T. S. Chung, "Draw solutions for forward osmosis processes: Developments, challenges, and prospects for the future," J. Membr. Sci., vol. 442, pp. 225-237, 2013.

[37] M. Mulder, Basic Principles of Membrane Technology. Dordrecht, The Netherlands, 1991.

[38] J. C. Ortega-Bravo, G. Ruiz-Filippi, A. Donoso-Bravo, I. E. Reyes, and D. Jeison, "Forward osmosis: Evaluation thin-film-composite membrane for municipal sewage concentration,” Chem. Eng. J., vol. 306, pp. 531-537, 2016.

List of Tables 
Table 1: Operating conditions used as recommended by each manufacturer.

Table 2: Ecotoxicity results.

Table 3: Jw, Js and SRSF measured for10 bar constant DSs osmotic pressure.

Table 4: Chemical costs of the process depending on the DS.

Table 5: DS Decision matrix for the demonstration plant.

List of Figures

Figure 1: Schematic drawing of the pilot plant.

Figure 2: Osmotic pressure versus DS concentration.

Figure 3: Conductivity of DS versus concentration.

Figure 4: Flux comparison among different DS in the same operation conditions.

Figure 5: Membrane performance comparison. 


\begin{tabular}{|c|c|c|c|c|c|}
\hline $\begin{array}{c}\text { Membrane } \\
\text { Configuration }\end{array}$ & $\begin{array}{r}\text { Area } \\
\left(m^{2}\right)\end{array}$ & $\begin{array}{l}\text { Maximum } \\
\text { Inlet } \\
\text { Pressure } \\
\text { (bar) }\end{array}$ & $\begin{array}{c}\text { Feed } \\
\text { Water } \\
\text { Pressur } \\
\text { e Inlet } \\
\text { (bar) }\end{array}$ & $\begin{array}{c}\text { DS } \\
\text { Pressure } \\
\text { Inlet } \\
\text { (bar) }\end{array}$ & $\begin{array}{c}\text { Start-up } \\
\text { procedure }\end{array}$ \\
\hline $\begin{array}{c}\text { Spiral Wound } \\
\text { TFC }\end{array}$ & 4.12 & 10 & 1.13 & 0.65 & $\begin{array}{c}\text { RO mode: } \\
\text { Flushing (DI } \\
\text { water, } 30^{\circ} \mathrm{C}, 30 \\
\text { min, } 7 \text { bar and } \\
8 \% \text { of recovery) }\end{array}$ \\
\hline $\begin{array}{c}\text { Spiral Wound } \\
\text { CTA }\end{array}$ & 3 & 4 & 1.10 & 0.60 & \\
\hline $\begin{array}{c}\text { Spiral Wound } \\
\text { TFC }\end{array}$ & 3 & 4 & 1.10 & 0.60 & $\begin{array}{c}\text { FO mode: } \\
\text { Flushing (both } \\
\text { streams, DI } \\
\text { water } 20^{\circ} \mathrm{C} .100\end{array}$ \\
\hline Flat Sheet TFC & 1.3 & 1 & 0.42 & 0.27 & $\begin{array}{c}\mathrm{cm} / \mathrm{s}, \mathrm{FW} \\
\text { pressure-DS } \\
\text { pressure }>0.2 \text { bar, } \\
30 \mathrm{~min}\end{array}$ \\
\hline CTA & 25 & 5 & 3.00 & 2.00 & \\
\hline
\end{tabular}




\begin{tabular}{|c|c|c|c|c|c|}
\hline$D S$ & $\begin{array}{c}\text { Concentration } \\
\left.\text { ( } \mathrm{g} \mathrm{g}^{-1} \text { water }\right)\end{array}$ & $\begin{array}{c}\text { Osmotic } \\
\text { pressure } \\
\text { (bar) }\end{array}$ & $p H$ & $\begin{array}{c}E C_{50} \\
\left(\mathrm{~g} \mathrm{~g}^{-1} \text { water }\right)\end{array}$ & Toxicity \\
\hline \multirow[t]{2}{*}{$\mathrm{K}_{4} \mathrm{P}_{2} \mathrm{O}_{7}$} & 0.11 & 21.33 & 10.14 & ND & ND \\
\hline & 0.11 & 21.41 & 8.19 & -- & Non toxic \\
\hline \multirow[t]{2}{*}{$\mathrm{HCOOK}$} & 0.04 & 20.68 & 10.09 & ND & ND \\
\hline & 0.04 & 20.70 & 8.10 & -- & Non toxic \\
\hline \multirow[t]{2}{*}{$\mathrm{MgSO}_{4}$} & 0.10 & 22.42 & 9.01 & ND & ND \\
\hline & 0.10 & 22.51 & 7.98 & -- & Non toxic \\
\hline $\begin{array}{c}\text { Sodium } \\
\text { polyacrylate }\end{array}$ & 0.58 & 19.29 & 6.88 & -- & Non toxic \\
\hline \multirow{2}{*}{$\begin{array}{l}\text { Polyethylene } \\
\text { glycol }\end{array}$} & 0.23 & 15.48 & 2.44 & ND & ND \\
\hline & 0.23 & 25.54 & 6.77 & $1.1 \cdot 10^{-3}$ & Toxic \\
\hline
\end{tabular}

ND: Not determined because the sample did not meet $\mathrm{pH}$ test requirement. 


\begin{tabular}{c|ccc}
\hline $\boldsymbol{D S}$ & $\begin{array}{c}\boldsymbol{J w} \\
\left(\boldsymbol{L} \boldsymbol{m}^{-2} \boldsymbol{h}^{-\mathbf{1}}\right)\end{array}$ & $\begin{array}{c}\boldsymbol{J} \boldsymbol{s} \\
\left(\mathbf{g ~ m}^{-2} \boldsymbol{h}^{-\mathbf{1}}\right)\end{array}$ & $\begin{array}{c}\boldsymbol{J} / \boldsymbol{J w} \\
\left(\mathbf{g ~ \boldsymbol { L } ^ { - 1 }}\right)\end{array}$ \\
\hline $\begin{array}{c}\text { Sodium } \\
\text { polyacrylate }\end{array}$ & 5.36 & 0.27 & 0.05 \\
$\mathrm{HCOOK}$ & 8.27 & 5.38 & 0.65 \\
$\mathrm{MgSO}_{4}$ & 4.86 & 0.97 & 0.20 \\
$\mathrm{~K}_{4} \mathrm{P}_{2} \mathrm{O}_{7}$ & 5.87 & 5.87 & 1.00 \\
$\mathrm{NaCl}$ & 5.38 & 4.04 & 0.75 \\
\hline
\end{tabular}




\begin{tabular}{|c|c|c|c|c|c|c|}
\hline$D S$ & $\begin{array}{c}J s / J w^{(1)} \\
K g m^{-3}\end{array}$ & $\begin{array}{c}\text { DS losses in } \\
\text { permeate }^{(2)} \\
\mathrm{Kg} \mathrm{m}^{-3}\end{array}$ & $\begin{array}{c}\text { Cost of } \\
\text { product }^{(3)} \\
\qquad K^{-1}\end{array}$ & $\begin{array}{c}\text { Cost of } \\
\text { replacement } \\
\epsilon m^{-3}\end{array}$ & $p H$ & $\begin{array}{c}p H \\
\text { adjustment }\end{array}$ \\
\hline $\mathrm{NaCl}$ & 0.75 & 0.26 & 0.22 & 0.22 & Neutral & N/A \\
\hline $\begin{array}{c}\text { Sodium } \\
\text { polyacrylate }\end{array}$ & 0.05 & 4.58 & 1.49 & 6.90 & Neutral & N/A \\
\hline $\begin{array}{l}\text { Polyethylene } \\
\text { glycol }\end{array}$ & No data & No data & No data & No data & $2-3$ & Significant \\
\hline HCOOK & 0.65 & 0.31 & 5.93 & 5.69 & $\sim 10$ & Significant \\
\hline $\mathrm{MgSO}_{4}$ & 0.20 & 0.96 & 0.98 & 1.14 & $8-9$ & N/A \\
\hline $\mathrm{K}_{4} \mathrm{P}_{2} \mathrm{O}_{7}$ & 1.00 & 0.86 & 4.56 & 8.48 & $\sim 10$ & Significant \\
\hline
\end{tabular}

(1) $\mathrm{Js} / \mathrm{Jw}$ measured empirically in section 3.1.2.

(2) Calculated by simulating that Diluted DS ( $\Pi=10$ bars) was recovered by a membrane with $99.9 \%$ of salt rejection.

(3) DS price is referred to a small-scale order. The prices are really dependent on the region and provider, these can be modified. 


\begin{tabular}{|c|c|c|c|c|c|c|}
\hline$D S$ & $\begin{array}{c}D S \\
\text { replacement }\end{array}$ & $\begin{array}{c}\text { Operating c } \\
\text { Energy of the } \\
\text { recovery } \\
\text { process }\end{array}$ & $\begin{array}{l}\text { osts } \\
\quad \text { pH } \\
\text { adjustment }\end{array}$ & $\begin{array}{c}\text { FO } \\
\text { Flux }\end{array}$ & $\begin{array}{c}\text { Effluent } \\
\text { quality } \\
\text { (toxicity) }\end{array}$ & $\begin{array}{c}\text { Sunlight and } \\
\text { thermal } \\
\text { stability }\end{array}$ \\
\hline $\mathrm{NaCl}$ & + & - & + & + & + & + \\
\hline $\mathrm{K}_{4} \mathrm{P}_{2} \mathrm{O}_{7}$ & -- & + & $-(1)$ & + & + & + \\
\hline HCOOK & - & - & $-(1)$ & ++ & + & + \\
\hline $\mathrm{MgSO}_{4}$ & + & + & + & - & + & + \\
\hline $\begin{array}{c}\text { Sodium } \\
\text { Polyacrylate }\end{array}$ & -- & ++ & + & + & + & + \\
\hline $\begin{array}{c}\text { Polyethylene } \\
\text { Glycol }\end{array}$ & No data & ++ & - & No data & - & No data \\
\hline
\end{tabular}

1) Costs associated to boron removal improvement were not considered. 


\section{Figure}

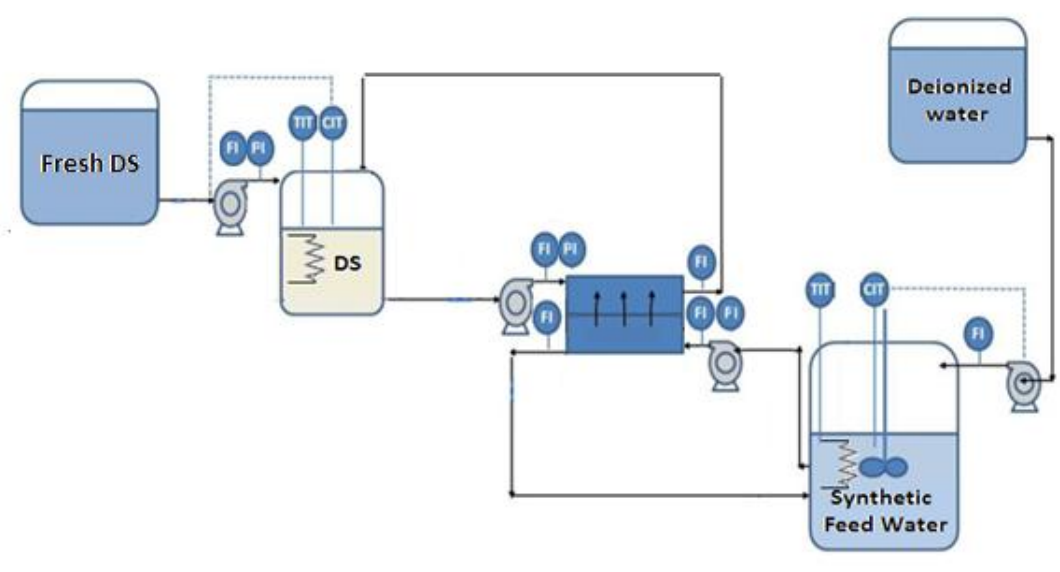

$$
\text { . }
$$

.

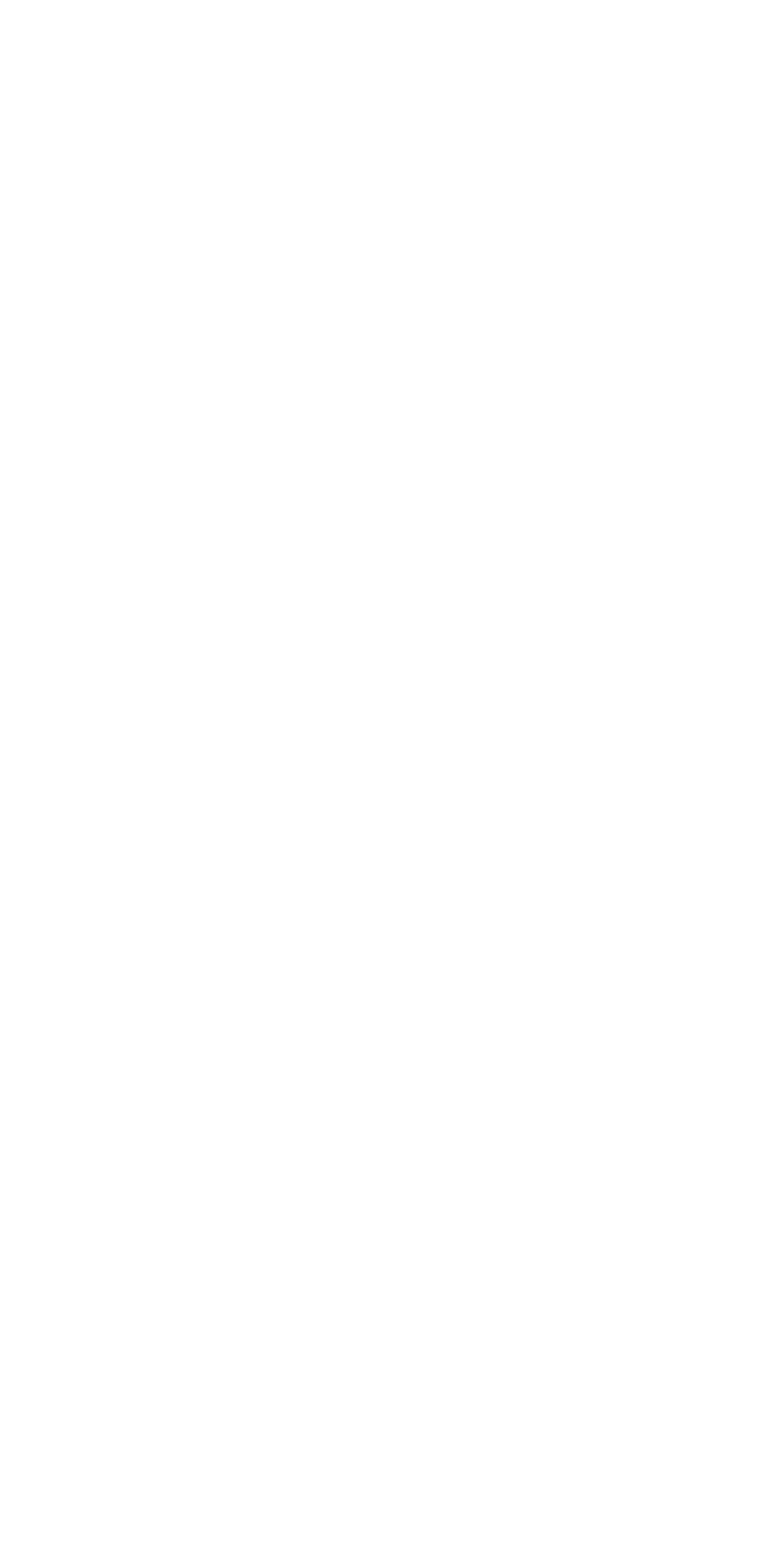




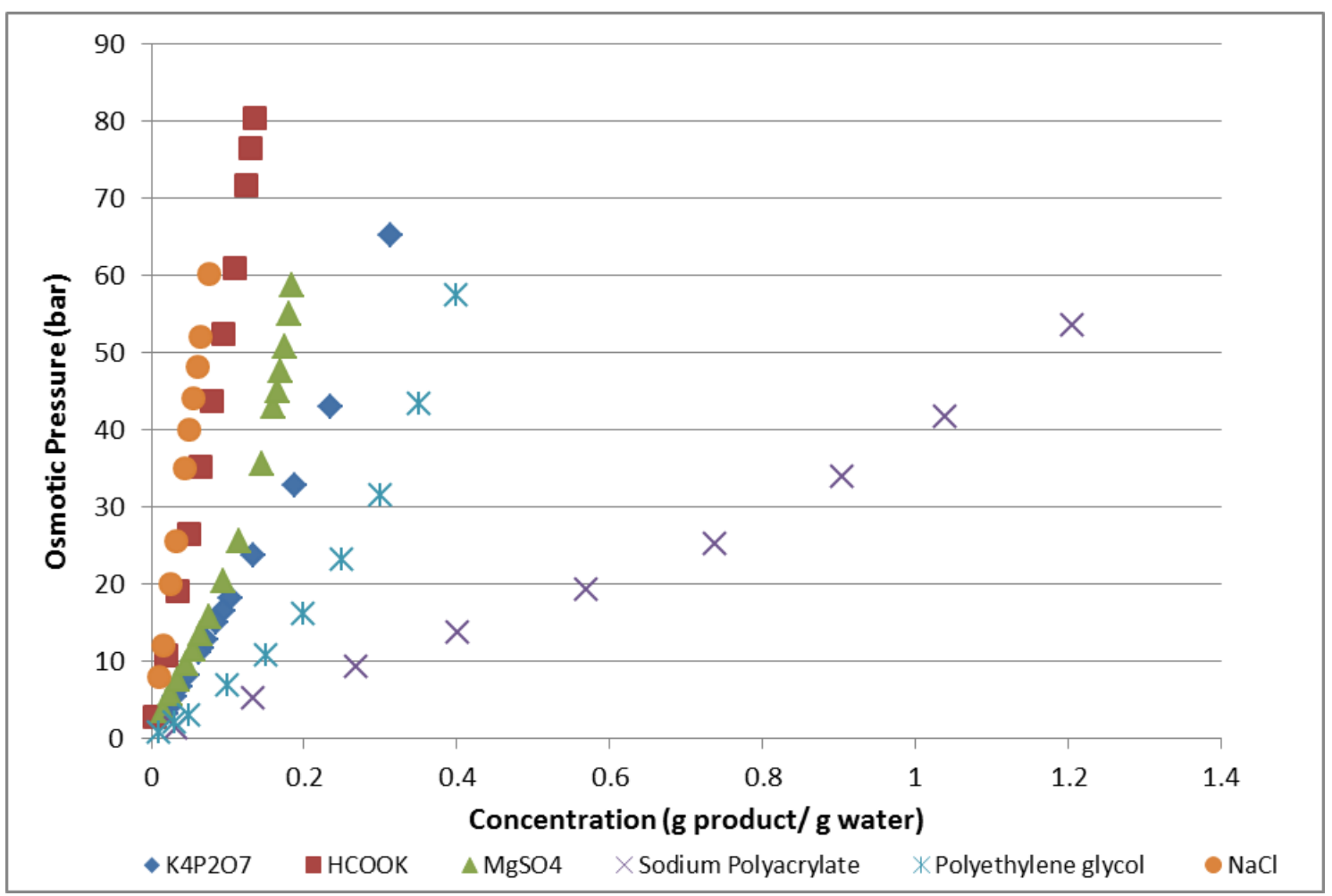




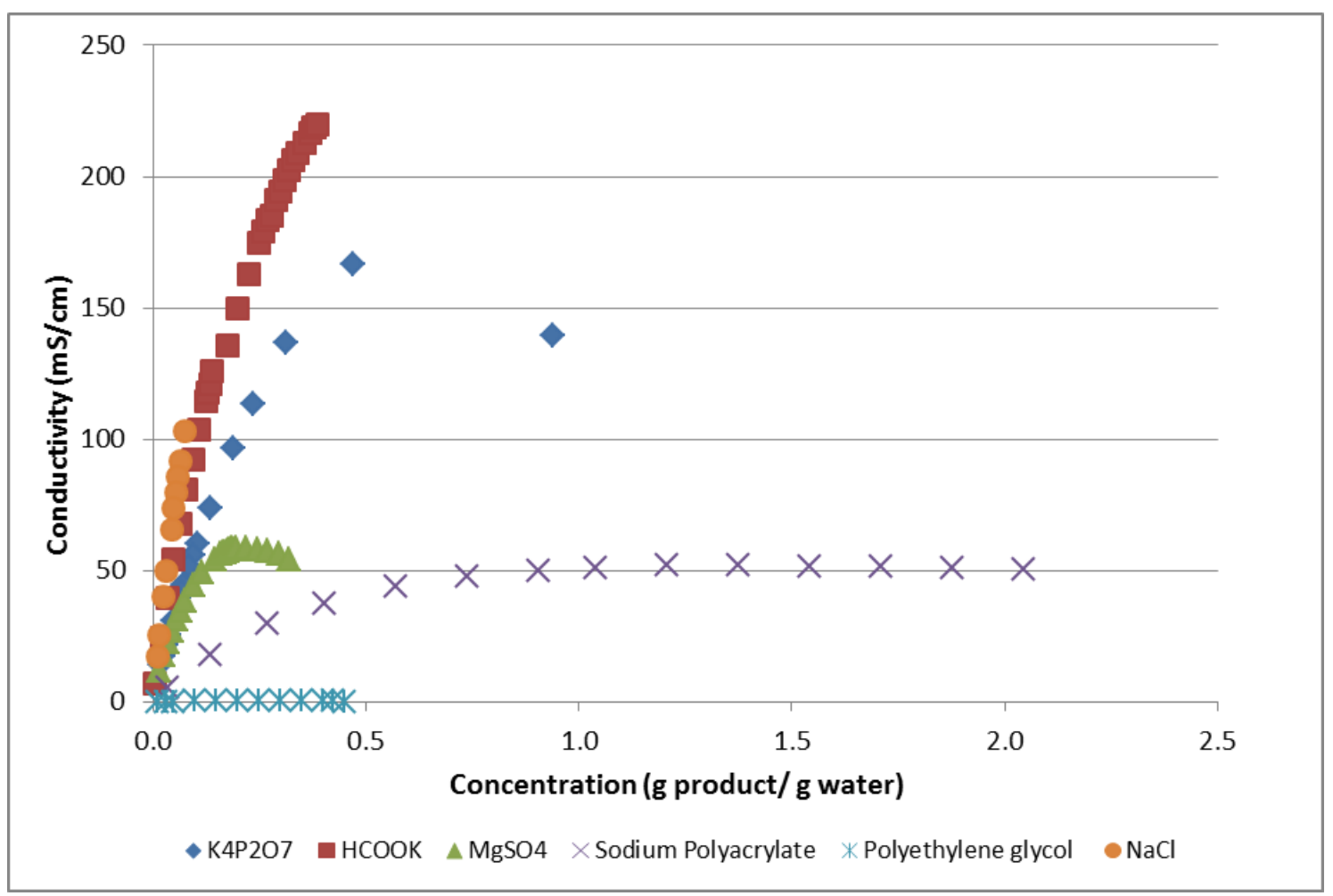




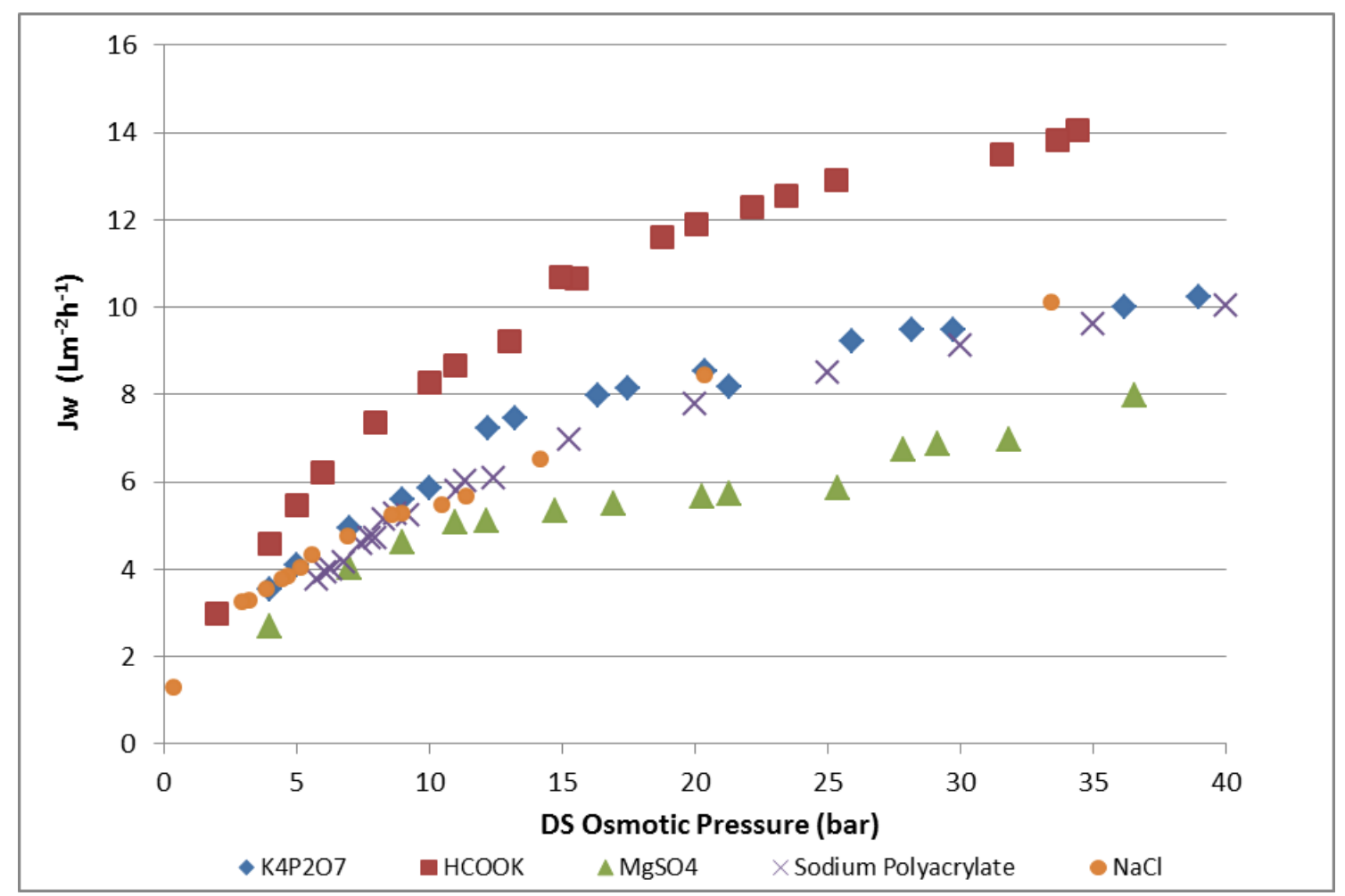


Figure

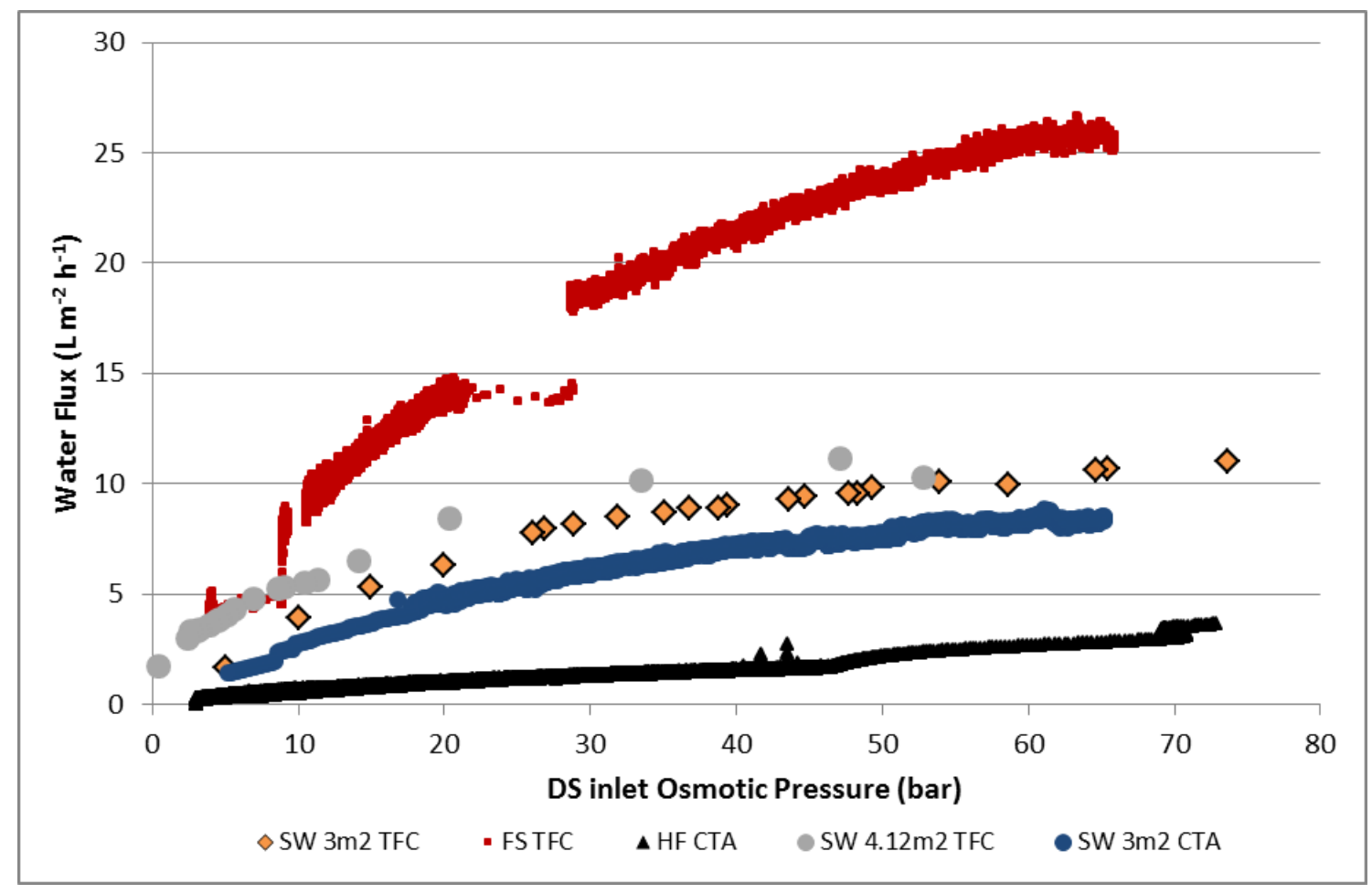

